\title{
Quantifying the Effect of Building Shadowing and Cloudiness on Mean Radiant Temperature in Singapore
}

\author{
Juan A. Acero ${ }^{1, *} \mathbb{C}$, Elliot J. Y. Koh ${ }^{1}$, Yon Sun Tan ${ }^{1}$ and Leslie K. Norford ${ }^{2}$ \\ 1 Singapore-MIT Alliance for Research and Technology, 1 Create Way \#09-03, Singapore 138602, Singapore; \\ elliotkoh91@gmail.com (E.J.Y.K.); yonsun@smart.mit.edu (Y.S.T.) \\ 2 Massachusetts Institute of Tecnology (MIT), 265 Massachusetts Ave, Cambridge, MA 02139, USA; \\ lnorford@mit.edu \\ * Correspondence: juanangel@smart.mit.edu; Tel.: +65-98136760
}

check for

updates

Citation: Acero, J.A.; Koh, E.J.Y.; Tan, Y.S.; Norford, L.K. Quantifying the Effect of Building Shadowing and Cloudiness on Mean Radiant Temperature in Singapore. Atmosphere 2021, 12, 1012. https://doi.org/ 10.3390/atmos12081012

Academic Editors: Dragan Milosevic, Britta Jänicke, Yuliya Dzyuban and Michael Allen

Received: 23 June 2021

Accepted: 3 August 2021

Published: 6 August 2021

Publisher's Note: MDPI stays neutral with regard to jurisdictional claims in published maps and institutional affiliations.

Copyright: (c) 2021 by the authors. Licensee MDPI, Basel, Switzerland. This article is an open access article distributed under the terms and conditions of the Creative Commons Attribution (CC BY) license (https:/ / creativecommons.org/licenses/by/ $4.0 /)$.

\begin{abstract}
Improving the quality of life in urban areas has become a major concern in the last few decades. With a constantly increasing urban population and in a climate change context, detailed knowledge of the impact of urban elements on the outdoor thermal environment is relevant. In this work, we present the results of several climatic campaigns carried out in Singapore aiming to evaluate local urban climate variables. Sensors were deployed simultaneously in different sites. The effect of building shadowing in the diurnal cycle of mean radiant temperature $\left(\mathrm{T}_{\mathrm{mrt}}\right)$ is evaluated in different seasons. Although during the Inter-Monsoon season, mean $\mathrm{T}_{\text {mrt }}$ reduction due to building shadow is $\approx 19^{\circ} \mathrm{C}$, during clear skies days, it can be reduced by $\approx 30^{\circ} \mathrm{C}$. The $\mathrm{T}_{\mathrm{mrt}}$ difference between sites is analyzed based on the weather conditions, the sky view factor (SVF), and the type of surrounding urban elements. Under building shadow conditions, higher SVF showed higher $\mathrm{T}_{\mathrm{mrt}}$ values, although no correlation was found between $\mathrm{T}_{\mathrm{mrt}}$ and diffuse solar radiation (measured above the urban canopy). The results suggest a relevant contribution of other radiation components (e.g., longwave radiation). The quantitative analysis of the $\mathrm{T}_{\mathrm{mrt}}$ provided in this work is relevant for outdoor thermal comfort strategies in tropical areas such as Singapore.
\end{abstract}

Keywords: mean radiant temperature; measurements; cloudiness; building shadow; seasonal difference; tropics

\section{Introduction}

With the aim of improving outdoor thermal comfort (OTC) in urban areas, research and studies have been increasingly carried out during the last decades. One of the main drivers is the necessity of adapting urban areas to climate change where the population will continue to grow in the future [1]. Urban heat mitigation strategies can help minimize the increase of air temperature inside the urban fabric [2-5], but they do not in all cases improve OTC [6-8].

Outdoor thermal comfort in urban areas is highly governed by the urban morphology. Many studies have pointed to street orientation and street aspect ratio as the most relevant parameters to determine outdoor thermal comfort levels [9-14]. However, other urban characteristics can also play an important role. Urban materials [15,16], the presence of vegetation [17-19], and anthropogenic heat emissions [20,21] can modify significantly OTC levels inside the urban area.

Several meteorological parameters (air temperature, humidity, wind speed, and radiation) influence thermal comfort levels. Between these variables, radiation has a relevant impact in outdoor thermal comfort [22]. However, the heat exchange by radiation between the human being and the outdoor spaces is complex due to the existence of heterogeneous longwave and shortwave radiant flux densities [23], which are influenced by the surrounding landscape. Mean radiant temperature $\left(\mathrm{T}_{\mathrm{mrt}}\right)$ is a measure of how human beings experience radiation. It is defined as "the uniform temperature of an imaginary enclosure 
in which the radiant heat transfer from the human body equals the radiant heat transfer in the actual non-uniform enclosure" [24]. Different studies have shown and quantified the influence of $\mathrm{T}_{\mathrm{mrt}}$ in human thermal comfort in outdoor spaces [25-28]. While different methods to estimate outdoor $\mathrm{T}_{\mathrm{mrt}}$ are available [27], a common and simple approach to measure $\mathrm{T}_{\mathrm{mrt}}$ is the use of the globe thermometer $[29,30]$.

Urban morphology has an important influence on $\mathrm{T}_{\mathrm{mrt}}$ at the pedestrian level [31-33]. $\mathrm{T}_{\mathrm{mrt}}$ spatial and temporal variations are highly conditioned by shortwave radiation variations, although the longwave radiation (particularly the lateral flux) contributes the majority of $\mathrm{T}_{\mathrm{mrt}}$ magnitude at all times of the day and sites [22,34].

Similarly to Middel and Krayenhoff [34], in Arizona, Tan et al. [28] reported a correlation between sky view factor and $\mathrm{T}_{\mathrm{mrt}}$ in Singapore. Higher SVF was associated to higher $\mathrm{T}_{\mathrm{mrt}}$ values. For clear sunny days, differences in daily $\mathrm{T}_{\mathrm{mrt}}$ peak between several urban spaces could reach $25^{\circ} \mathrm{C}$, with the highest $\mathrm{T}_{\mathrm{mrt}}$ peak value reaching approximately $68^{\circ} \mathrm{C}\left(\mathrm{SVF}=0.671\right.$ and solar irradiance slightly lower than $\left.900 \mathrm{Watt} / \mathrm{m}^{2}\right)$ [28]. Similar values were reported in Chandigarh (India) with maximum peak values of $69.3{ }^{\circ} \mathrm{C}$ on a clear sky day [23], and in Taiwan, $70.9^{\circ} \mathrm{C}$ [35]. In Tempe (Arizona), maximum values reached $84.9^{\circ} \mathrm{C}$, and maximum differences between shaded and sun-exposed sites were close to $40^{\circ} \mathrm{C}$. Results highlighted the influence of urban forms, sky view factors, and solar radiation regimens on $\mathrm{T}_{\mathrm{mrt}}[34,36]$.

In addition to the effect of urban morphology on $\mathrm{T}_{\mathrm{mrt}}$ (e.g., by means of building shadowing), weather conditions also influence $\mathrm{T}_{\mathrm{mrt}}$ at the pedestrian level. Specifically, cloud cover can reduce incoming solar radiation up to $80-90 \%$. Generally, higher cloud cover will reduce the direct solar radiation while the diffuse solar radiation component will increase [37,38]. Additionally, solar elevation also influences the amount of diffuse solar radiation. Lower solar elevations will tend to increase the diffuse component due to the larger path of the radiation through the atmosphere [39,40]. Since the SVF influences the amount of direct and diffuse solar radiation components inside an urban canyon, the alteration of these radiation components (e.g., due to cloud cover) will further condition $\mathrm{T}_{\text {mrt }}$ levels [36].

This study seeks to analyze the influence of urban geometry and incoming solar radiation on mean radiant temperature to support climate-conscious urban planning and design in a hot and humid environment similar to Singapore. Both high-rise and lowrise urban developments are considered. Based on extensive measurement campaigns, the impact of building shadow and sky view factor on $\mathrm{T}_{\mathrm{mrt}}$ is evaluated under different weather conditions and in different climatic seasons.

\section{Regional Climate}

Singapore is a highly populated island $\left(712 \mathrm{~km}^{2}\right)$ where 5.6 million people live [41]. It is located $\left(1^{\circ} 18^{\prime} 52.79^{\prime \prime} \mathrm{N}\right.$ and $\left.103^{\circ} 50^{\prime} 43.47^{\prime \prime} \mathrm{E}\right)$ at the south of the Malayan Peninsula. Its climate is classified as tropical rainforest (Koppen climate classification Af) characterized by uniform high temperatures along the year $\left(\approx 27.5^{\circ} \mathrm{C}\right)$, high relative humidity, and significant precipitation $\approx 2190 \mathrm{~mm}$ [42].

Regional climate throughout the year is mostly governed by Asian monsoons. They influence cloudiness, surface wind speed, and wind direction [43]. The northeast (NE) monsoon season (December to March) presents higher precipitation levels ( $>250 \mathrm{~mm} / \mathrm{month})$ and surface wind speeds. In the southwest (SW) monsoon season, between June and September, lower precipitation occurs $(\approx 150 \mathrm{~mm} / \mathrm{month})$ and surface winds are generally from south to southwest, mostly opposite to the NE-Monsoon. Between these two seasons, periods of low winds occur (close to calm situations, especially inland) with variable wind direction. These are the Inter-Monsoon season. The October and November period is called the wet Inter-Monsoon because higher precipitation occurs compared to the dry Inter-Monsoon (April and May). During these periods, sea breezes can develop and affect Singapore. 


\section{Materials and Methods}

To evaluate the impact of urban planning and design on OTC in Singapore, several measurement campaigns were carried out in two areas during 2019 and 2020 [44]. In each area, $4-5$ sites with different thermal characteristics were selected. In each site, a set of sensors were deployed to measure local climate variables. This paper is focused on the effect of building shadowing and SVF on mean radiant temperature $\left(\mathrm{T}_{\mathrm{mrt}}\right)$ in different solar radiation conditions, so we will present only the measuring sites relevant for this purpose (Section 3.1). A complete description of the campaigns is presented in Acero et al. [44].

\subsection{Measurement Campaigns}

Two campaigns of several months were carried out in two different urban areas of Singapore. In each area, several sets of instruments were deployed to measure simultaneously the microclimate conditions at specific sites (see Section 3.2). Sensors operated continuously throughout the campaign. The following climate variables were measured: air temperature $\left(T_{a}\right)$, relative humidity $(R H)$, wind speed $(W S)$, wind direction $(W D)$, precipitation $\left(R_{a}\right)$, and globe temperature $\left(\mathrm{T}_{\mathrm{g}}\right)$. For the first five variables the Weather Transmitter WXT520 of Vaisala was used. Vapor pressure (e) was derived from $\mathrm{T}_{\mathrm{a}}, \mathrm{RH}$, and the saturation vapor pressure of water [45]. $\mathrm{T}_{\mathrm{g}}$ measurements were carried out with the black globe radiant temperature device (150 $\mathrm{mm}$ of diameter) of Scientific Campbell.

At each site, both sensors were mounted on a reinforced metallic arm and attached to a lamp post (Figure 1). The metallic arm extended around $1.2 \mathrm{~m}$ away from the lamp post to avoid wind obstructions. All sensors were between 2.2 and $2.4 \mathrm{~m}$ above the ground level to comply with governmental agencies' requirements.

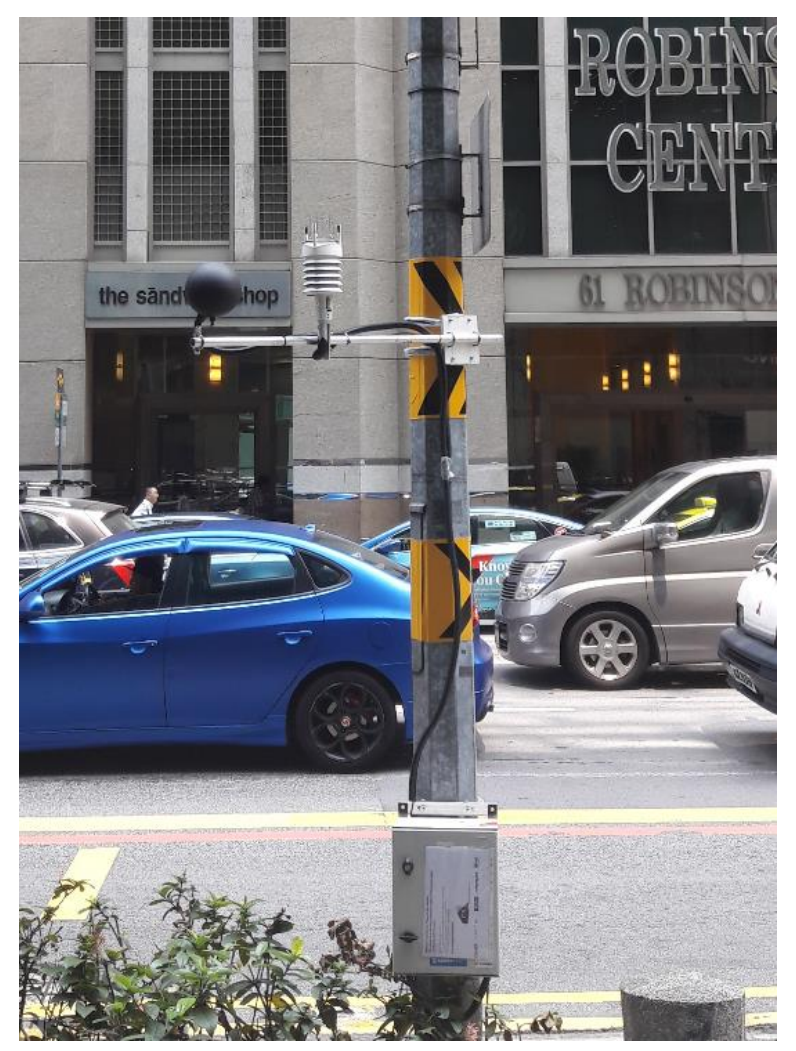

Figure 1. Visual description of the sensors deployed in each site.

A data logger (Scientific Campbell CR300) was used to store 1-min average values recorded by the sensors. Together with the necessary battery (18 Amph at $12 \mathrm{~V})$ to power all the instruments at each site, the data logger was secured in a waterproof enclosure attached to the same lamp post. 
The sensors provided the following accuracy for the measurements: $\pm 0.3^{\circ} \mathrm{C}$ for $\mathrm{T}_{\mathrm{a}}$ and $\mathrm{T}_{\mathrm{g}}, \pm 3 \%$ for $\mathrm{RH}, \pm 3 \%$ for $\mathrm{WS}, \pm 3^{\circ}$ for $\mathrm{WD}$, and $<5 \%$ for rainfall.

$\mathrm{T}_{\mathrm{mrt}}$ was derived from measurements using Formula (1) where a mean convection coefficient [24] is specifically defined for Singapore [46]:

$$
\mathrm{T}_{\mathrm{mrt}}=\left[\left(\mathrm{T}_{\mathrm{g}}+273.15\right)^{4}+\frac{0.82 \times 10^{8} \mathrm{WS}^{0.46}}{\in \mathrm{D}^{0.4}}\left(\mathrm{~T}_{\mathrm{g}}-\mathrm{T}_{\mathrm{a}}\right)\right]^{1 / 4}-273.15
$$

where $T_{g}$ is the globe temperature $\left({ }^{\circ} \mathrm{C}\right)$, WS is the wind speed $\left(\mathrm{ms}^{-1}\right), \mathrm{T}_{\mathrm{a}}$ is the air temperature $\left({ }^{\circ} \mathrm{C}\right)$, D is the globe diameter $(\mathrm{m})$, and $\epsilon$ is the globe emissivity. In our case, $\epsilon=0.95$ (for black globe).

Additionally, 10-min values of global solar irradiance measured in station 322 of the Solar Energy Research Institute in Singapore (SERIS) were used to evaluate the level of cloudiness during the measurement campaign. This station is located on a roof (above the urban canopy) close to the two areas (Section 3.2) where sensors were deployed. Although cloudiness in Singapore can vary significantly in short distances, it is considered that the measured global and diffuse solar radiation in station 322 is representative of the areas of study. The uncertainty of the irradiance sensors is 5\% [47].

\subsection{Areas and Sites of Measurements}

Two different areas of Singapore (Duxton Park and the Commercial and Business District (CBD)) were selected to deploy several sensors simultaneously (Figure 2). Specific measuring sites inside each area were selected to provide relevant and representative data to analyze the impact on $\mathrm{T}_{\mathrm{mrt}}$ of building shadowing and cloudiness in different types of urban developments.
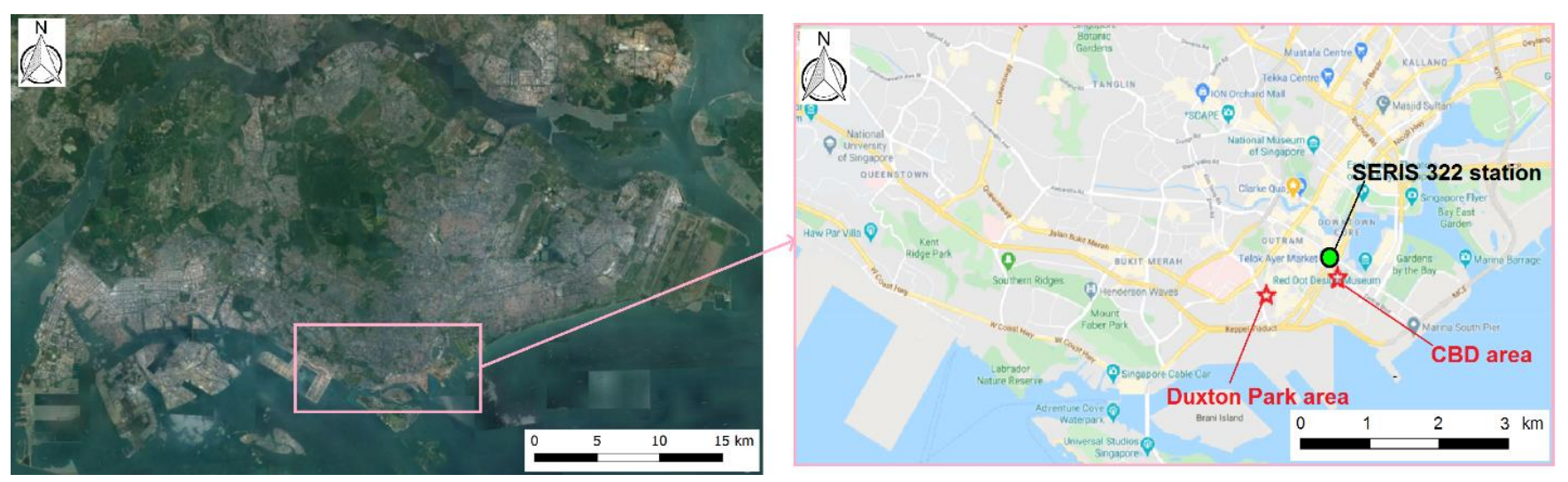

Figure 2. Location of the areas of study in Singapore (Duxton Park area and CDB area) as well as station 322 of the Solar Energy Research Institute of Singapore (SERIS) where solar irradiance values were obtained.

\subsubsection{Duxton Park Area}

The Duxton Park area is of particular interest because of its location and nature. Located close to the $\mathrm{CDB}$, the high-rise developed area of Singapore, it is mostly used by residents. It is a short, narrow, and green corridor that offers an alternative route compared to the more heavy trafficked nearby streets. In addition, the area combines different urban typologies (Figure 3). Different street canyon aspect ratios (the ratio between the street width and the aside averaged building height) and building height asymmetry (e.g., Pinnacle high-rise building versus low-rise shop-houses) can be found. 


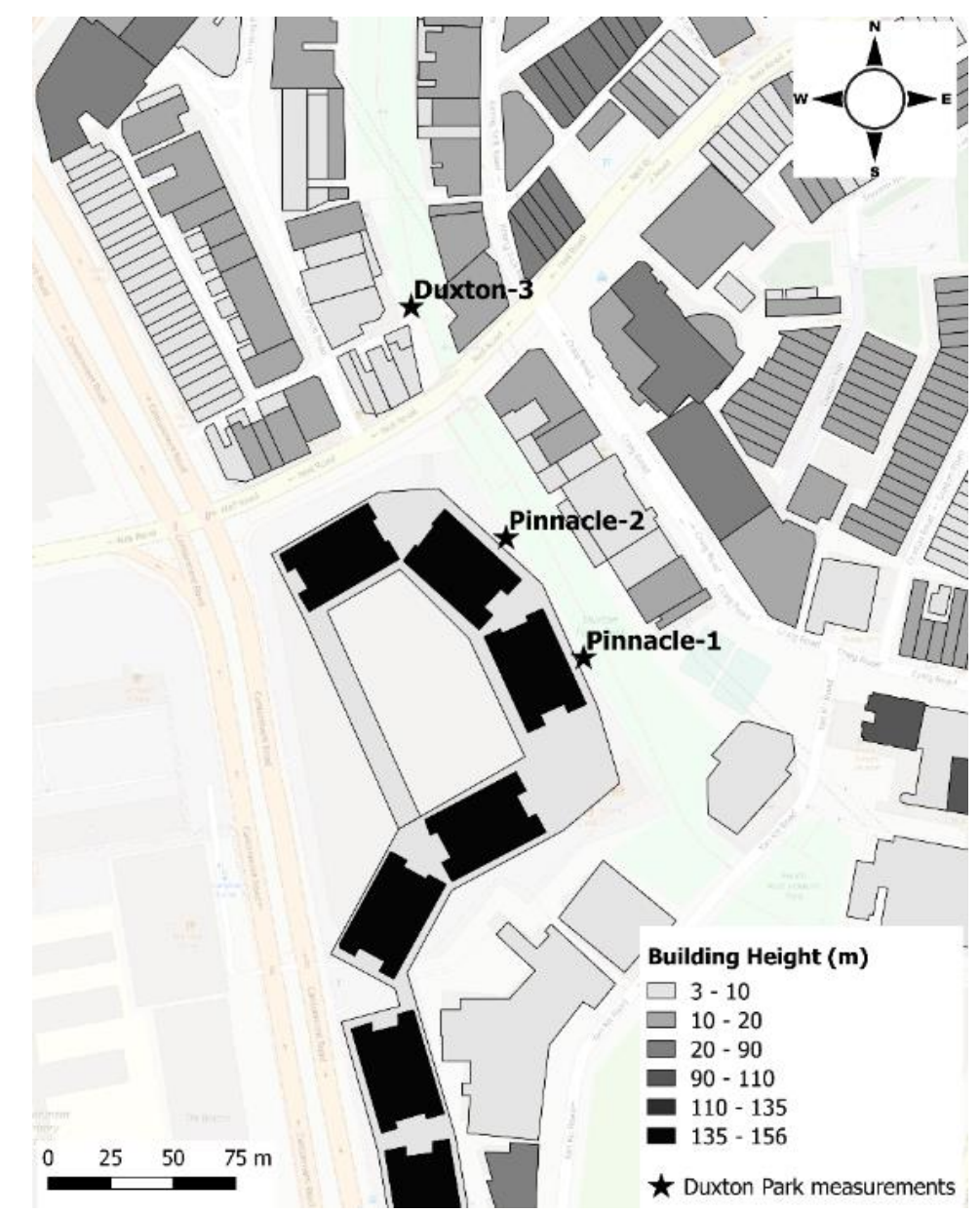

Figure 3. Location of the selected sites for the measurement campaign in the Duxton Park area.

Three sites (Pinnacle1, Pinnacle2, and Duxton3) have been selected to analyse the impact of urban typologies, building shadowing and cloud cover on $\mathrm{T}_{\mathrm{mrt}}$. In these sites, simultaneous measurements were carried out between 4 July and 23 October 2019 (3.5 months), including the SW-Monsoon season and part of the wet Inter-Monsoon season (see Section 2). A description of the specific sites where the sensors were located is presented in Table 1.

\subsubsection{CBD Area}

The high-rise CBD of Singapore is different to Duxton Park (Section 3.2.1) not only because of the type of urban development but also the activities carried out. It is the heart of Singapore's financial activities and is currently mostly used by office worker commuters. The area where the sensors were deployed is less than $0.3 \mathrm{~km}^{2}$ (Figure 4), around Robinson Road, and between Boon Tat Street and McCallum Street. It includes streets with different aspect ratios, street orientations (NE-SW and NW-SE), and building height asymmetry (e.g., BoonTat711 site), as described in Table 2.

At four outdoor sites (BoonTat711, BoonTatSt, RobinsonRd, and McCallumSt), measurements were carried out simultaneously between 15 November 2019 and 13 January 2020 (2 months), which includes the last part of the wet Inter-Monsoon season and the wet NE-Monsoon season (see Section 2). A description of the specific sites is presented in Table 2. 
Table 1. Description of the sites in the Duxton Park area where measurements were carried out.

\begin{tabular}{|c|c|c|c|}
\hline Site & Description & Picture & SVF $^{(1)}$ \\
\hline Pinnacle1 & $\begin{array}{l}\text { Asymmetrical street canyon (high-rise } \\
\text { buildings on one side and low-rise } \\
\text { development on the other). NW street } \\
\text { orientation. Shadow of high-rise building } \\
\text { in the afternoon and trees in the morning. }\end{array}$ & & \\
\hline Pinnacle2 & $\begin{array}{l}\text { Asymmetrical street canyon (high-rise } \\
\text { towers on one side and low-rise } \\
\text { development on the other). NW street } \\
\text { orientation. Shadow of high-rise building } \\
\text { in the afternoon. Influence of nearby low } \\
\text { height trees and bushes. }\end{array}$ & & \\
\hline Duxton3 & $\begin{array}{l}\text { Low-rise development area. Buildings on } \\
\text { both sides of the canyon are not higher } \\
\text { than } 10 \mathrm{~m} \text {. Ground mostly covered with } \\
\text { grass. NNW street orientation. Most } \\
\text { relevant shadow provided by some tall } \\
\text { palm trees (high transmissivity) before } \\
\text { noon. Site with highest sky view factor. }\end{array}$ & & \\
\hline
\end{tabular}

(1) Calculations were carried out with Rayman software [48,49].

Table 2. Description of the sites in the CBD area were measurements were carried out.

\begin{tabular}{|c|c|c|c|}
\hline Site & Description & Picture & SVF $^{(1)}$ \\
\hline BoonTat711 & $\begin{array}{l}\text { Asymmetrical street canyon (high-rise } \\
\text { buildings on one side and Telok Ayer Market } \\
\text { (low-rise development) on the other). Street } \\
\text { with NW-SE orientation. Shadow in the } \\
\text { afternoon due to high-rise building. Site with } \\
\text { unusual high SVF due to openness and } \\
\text { low-rise development in one side. }\end{array}$ & & SVI \\
\hline RobinsonRd & $\begin{array}{l}\text { High-rise development with street aspect } \\
\text { ratio } \approx 2.5 \text { (low sky view factor) and NE-SW } \\
\text { orientation. Only a short period }(\approx 2 \mathrm{~h} \text { ) of } \\
\text { direct solar radiation around } \\
\text { midday/afternoon. }\end{array}$ & & \\
\hline
\end{tabular}


Table 2. Cont.

\begin{tabular}{ccc}
\hline Site & Description \\
BoonTatSt & $\begin{array}{c}\text { Low-rise development with street aspect } \\
\text { ratio } \approx 1 \text { (high sky view factor), and NW-SE } \\
\text { orientation. Shadow during the afternoon. } \\
\text { Farthest site from the shore line. }\end{array}$ \\
McCallumSt & $\begin{array}{c}\text { ratio } \approx 2.5 \text { (low sky view factor), and NW-SE } \\
\text { orientation. Shadow of high-rise building in } \\
\text { the afternoon. }\end{array}$ \\
\hline
\end{tabular}

(1) Calculations were carried out with Rayman software [48,49]

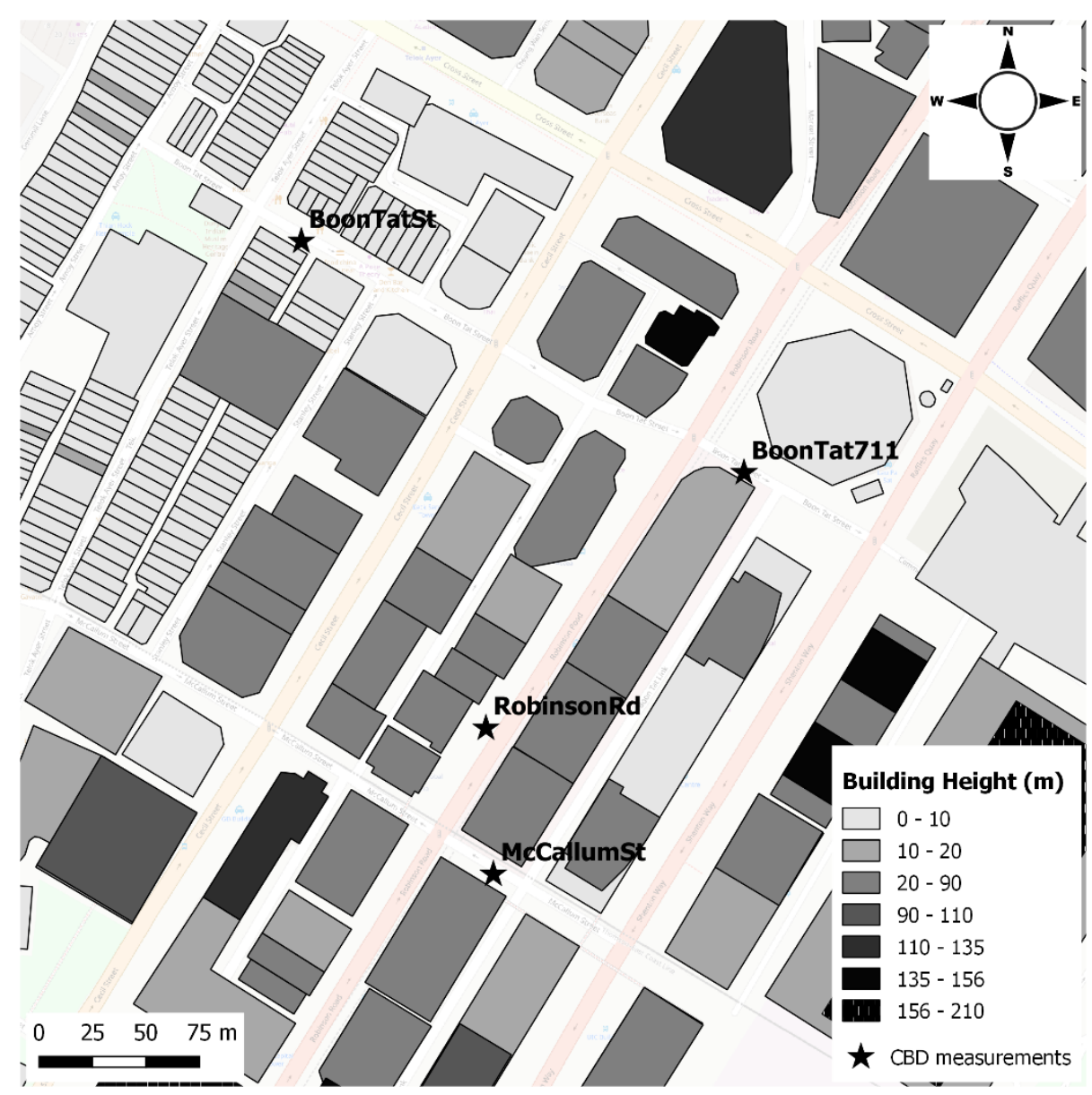

Figure 4. Location of the selected sites for the measurement campaign in the CBD area. 


\subsection{Analysis of Climate Variables}

At each site, 10-min mean climatic values were calculated from 1-min records stored in the data logger (see Section 3.1).

With the aim of analyzing the impact of high-rise buildings' shadow and cloud cover on $\mathrm{T}_{\mathrm{mrt}}$, diurnal cycles for different time periods (e.g., climatic seasons) were calculated. In addition, average values during the midday/afternoon period (11:10 to 16:00) were extracted to compare the daily highest $\mathrm{T}_{\mathrm{mrt}}$ values between different sites. The analysis was carried out for different climatic seasons as well as for specific days.

In Pinnacle1 and Pinnacle2 (Duxton Park area), two days (13 July and 11 October 2019) with clear skies were selected. At each site, $W S, T_{a}$ and $e$ mean afternoon values were similar during both days, although Pinnacle1 always registered higher WS and lower $T_{a}$ values (Table 3 ). When building shadow started to affect both sites, global radiation was $720 \mathrm{Watt} / \mathrm{m}^{2}$ and $1002 \mathrm{Watt} / \mathrm{m}^{2}$ on $13 \mathrm{July}$ and 11 October, respectively.

Table 3. Mean midday/afternoon climatic values (11-16 h) registered in Pinnacle1 and Pinnacle2 on 13 July and 11 October 2019.

\begin{tabular}{ccccc}
\hline Day & Site & WS $\left(\mathbf{m s}^{-\mathbf{1}}\right)$ & $\mathbf{T}_{\mathbf{a}}\left({ }^{\circ} \mathbf{C}\right)$ & $\boldsymbol{e}(\mathbf{h P a})$ \\
\hline \multirow{2}{*}{ 13 July } & Pinnacle1 & 1.7 & 31.1 & 24.9 \\
\cline { 2 - 5 } & Pinnacle2 & 1.0 & 32.2 & 25.3 \\
\hline \multirow{2}{*}{ 11 October } & Pinnacle1 & 1.4 & 31.1 & 25.3 \\
\cline { 2 - 5 } & Pinnacle2 & 0.8 & 31.6 & 25.4 \\
\hline
\end{tabular}

To analyze the influence of cloudiness and solar radiation in $\mathrm{T}_{\mathrm{mrt}}$, hourly values were evaluated against the clearness index defined as:

$$
\mathrm{K}_{\mathrm{t}}=\frac{\mathrm{GHI}}{\mathrm{GHI}_{\mathrm{CS}}}
$$

where GHI is the global horizontal irradiance and $\mathrm{GHI}_{\mathrm{CS}}$ is the clear skies global horizontal irradiance.

Thus, $K_{t}$ represents a dimensionless number between 0 and 1 , which is defined as the surface global radiation divided by the surface global radiation when conditions of clear skies occur (i.e., maximum transmission of solar radiation through the atmosphere).

For Singapore, Dazhi et al. [50] defined the $\mathrm{GHI}_{\mathrm{CS}}$ as:

$$
\mathrm{GHI}_{\mathrm{CS}}=0.8277 \cdot \mathrm{E}_{0} \cdot \mathrm{I}_{\mathrm{SC}} \cdot\left(\cos \theta_{\mathrm{z}}\right)^{1.3644} \cdot \mathrm{e}^{-0.0013 \cdot\left(90-\theta_{\mathrm{Z}}\right)}
$$

where $\mathrm{E}_{0}$ is an eccentricity correction factor of Earth, $\mathrm{I}_{\mathrm{sc}}$ is the solar constant $\left(1366.1 \mathrm{Watt} / \mathrm{m}^{2}\right)$, and $\theta_{z}$ is the solar zenith angle.

Correlation analysis between $\mathrm{T}_{\mathrm{mrt}}$ and $\mathrm{K}_{\mathrm{t}}$ have been undertaken for August 2019 at 10:30 and 17:00 for different sites (shaded and non-shaded).

Additionally, the diurnal cycle of $\mathrm{T}_{\mathrm{mrt}}$ was analyzed on a clear skies day and a cloudy day. Two days in the SW-Monsoon season (25 July and 1 August) were selected. These selected days were close to one another to avoid significant difference in the solar elevation (and the timing of $\mathrm{T}_{\mathrm{mrt}}$ peak values). In addition, no precipitation occurred during these days. On 25 July, the sky was covered with clouds throughout the day, with different levels of incoming solar radiation. On the contrary, 1 August presented during most of the day clear skies (high solar radiation), although some periods of clouds occurred before midday. Table 4 shows the mean and maximum solar irradiance registered in the area during different periods of the day. The mean wind conditions were very similar throughout the day, but the temperature was higher on 1 August (clear sky day). 
Table 4. Mean and maximum solar irradiance values (Watt $/ \mathrm{m}^{2}$ ) registered in station 322 of SERIS (close to Duxton Park) during different periods of the day on 25 July and 1 August 2019.

\begin{tabular}{|c|c|c|c|c|}
\hline Date & & $\begin{array}{c}\text { Morning } \\
\text { (7:00 to 10:00) }\end{array}$ & $\begin{array}{l}\text { Midday/Afternoon } \\
\text { (11:00 to 16:00) }\end{array}$ & $\begin{array}{c}\text { Evening } \\
\text { (17:00 to 19:00) }\end{array}$ \\
\hline \multirow{2}{*}{$\begin{array}{c}25 \text { July } \\
\text { (cloudy day) }\end{array}$} & Mean & 141 & 599 & 155 \\
\hline & Max. & 371 & 833 & 238 \\
\hline \multirow{2}{*}{$\begin{array}{c}1 \text { August } \\
\text { (clear skies day) }\end{array}$} & Mean & 207 & 738 & 188 \\
\hline & Max. & 593 & 987 & 361 \\
\hline
\end{tabular}

\section{Results and Discussion}

\subsection{Impact of Building Shadow}

In this section, the influence of the shadow of a high-rise building on $\mathrm{T}_{\mathrm{mrt}}$ is presented. Results are analyzed at the pedestrian level. The analysis is presented for different climatic seasons (mean values) and for two clear skies days when the impact of building shadow on $\mathrm{T}_{\mathrm{mrt}}$ is highest. Data registered both in Duxton Park and CBD (Section 3.2) are used to discuss the findings.

\subsubsection{Differences between Climatic Seasons}

Figure 5 presents the mean diurnal profile in Pinnacle1, Pinnacle2, and Duxton3 (Duxton Park area) during the SW-Monsoon and the wet Inter-Monsoon seasons. In all sites, $\mathrm{T}_{\mathrm{mrt}}$ peaks tend to occur later in time during the SW-Monsoon season. This can mostly be explained by the elevation of sun and the interference of the different urban elements/features with the incoming solar radiation. Although Duxton3 is not affected by building shadow, the influence on $\mathrm{T}_{\mathrm{mrt}}$ of some tall palm trees at 11:30-12:00 is notable [44]. Maximum mean $\mathrm{T}_{\mathrm{mrt}}$ values in Duxton 3 reach $59.4^{\circ} \mathrm{C}$ and $61.5^{\circ} \mathrm{C}$ in the wet Inter-Monsoon and SW-Monsoon seasons, respectively.

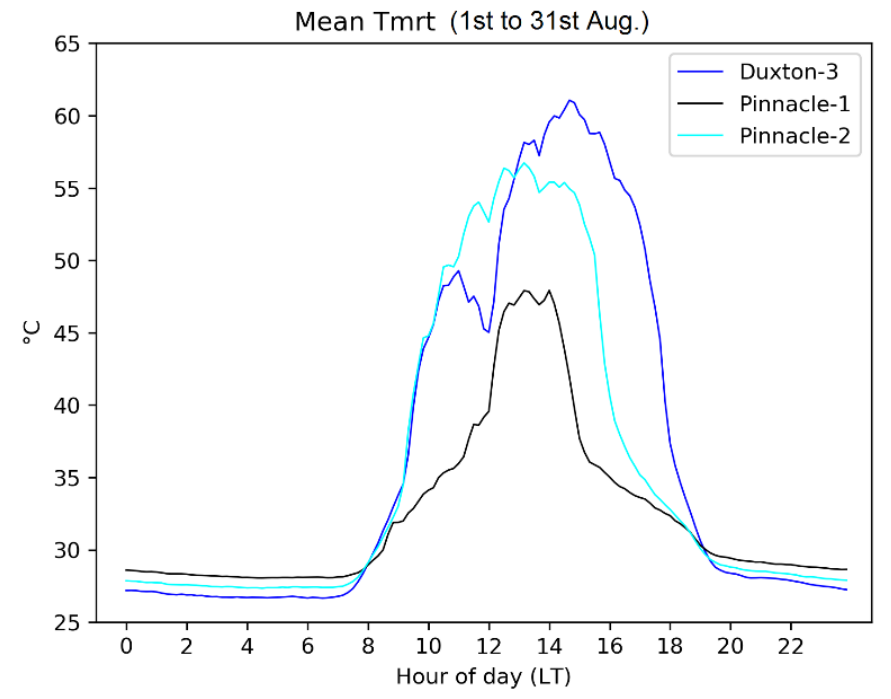

a)

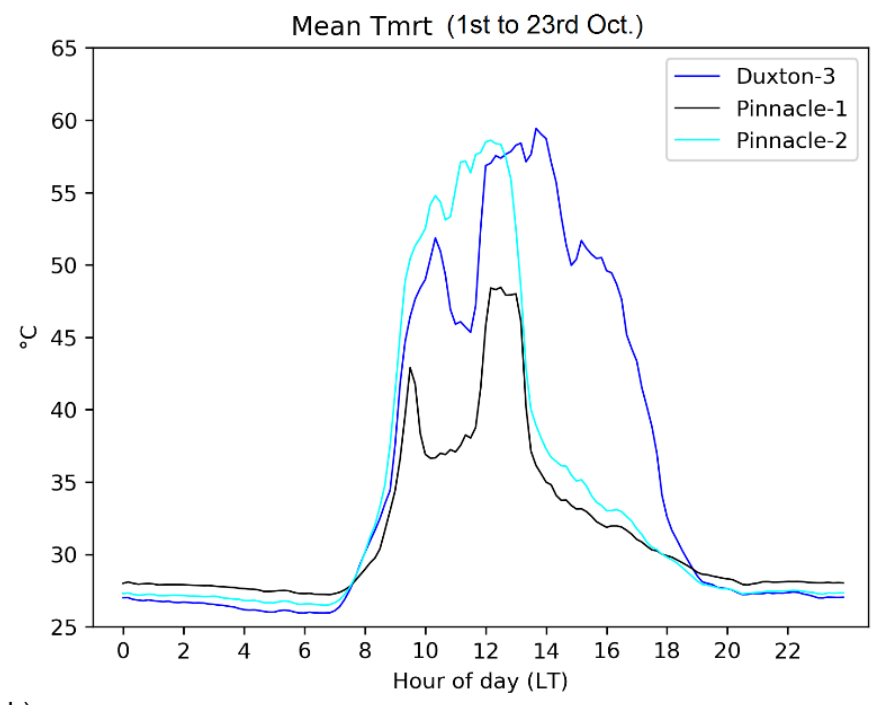

b)

Figure 5. Mean $\mathrm{T}_{\mathrm{mrt}}$ diurnal cycle (using 10-min averaged values) in Pinnacle1, Pinnacle2, and Duxton3 in Duxton Park in two different seasons: (a) SW-Monsoon (1 to 31 August 2019) and (b) Inter-Monsoon (1 to 23 October 2019).

The influence of the nearby high-rise buildings' shadow (Figure 3) is clearly noticed in Pinnacle1 and Pinnacle2 in the afternoon. In the Inter-Monsoon season, $\mathrm{T}_{\mathrm{mrt}}$ drops sharply at 12:40 in Pinnacle 2 and at 13:10 in Pinnacle1, with reductions mean $\mathrm{T}_{\mathrm{mrt}}$ of $\approx 19^{\circ} \mathrm{C}$ and $\approx 11^{\circ} \mathrm{C}$, respectively. Time differences between sites are attributed to different orientation $\left(21^{\circ}\right)$ of the buildings providing shadow. However, during the SW-Monsoon, the effect of 
building shadow is delayed $\approx 1.5 \mathrm{~h}$ with respect to the Inter-Monsoon in both sites due to the variation of the sun elevation and sun path between seasons.

The effect of building shadow (i.e., reduction of $\mathrm{T}_{\mathrm{mrt}}$ ) is much higher in Pinnacle2 than in Pinnacle1. Pinnacle2 drops $\approx 8^{\circ} \mathrm{C}$ more than Pinnacle1 in the Inter-Monsoon season. The reason for this difference between sites is that the Pinnacle1 measuring site is already (before the shadow of the building) under the influence of trees that partly block solar radiation.

After the sharp drop in mean $\mathrm{T}_{\mathrm{mrt}}$, under the building shadow, $\mathrm{T}_{\mathrm{mrt}}$ levels remain higher in Pinnacle2. This is best shown in the Inter-Monsoon season. During the afternoon (14:00 to 16:00), the difference between both sites can reach $2.5^{\circ} \mathrm{C}$. During this period of the day (both sites are under building shadow), the $\mathrm{T}_{\mathrm{mrt}}$ difference is due to lower levels of radiation in Pinnacle1. As commented previously, the latter is partly covered by trees that limit the access of diffuse solar radiation but also the surrounding surfaces are colder (e.g., leaves), reducing longwave irradiance in Pinnacle1.

Similar effects are observed in McCallumSt, BoonTatSt, BoonTat711, and RobinsonRd (CBD area). Figure 6 shows the different mean $\mathrm{T}_{\mathrm{mrt}}$ diurnal profile for a two-week period in the wet Inter-Monsoon (last half of November 2019) and in the wet NE-Monsoon (first half of January 2020). In this case, the timing of the peak values in each site is conditioned by the street orientation. McCallumSt, BoonTatSt, and BoonTat711 are all NW-oriented streets and have the peak at $\approx 10: 10$ in the Wet Inter-Monsoon season, while for RobinsonRd (a NE-oriented street), the peak happens $3.5 \mathrm{~h}$ later (at 13:40). In the wet NE-Monsoon period, the time lag between the two street orientations increases to $4 \mathrm{~h}$ due to the variation in the sun path (elevation and azimuth) with respect to the wet Inter-Monsoon.

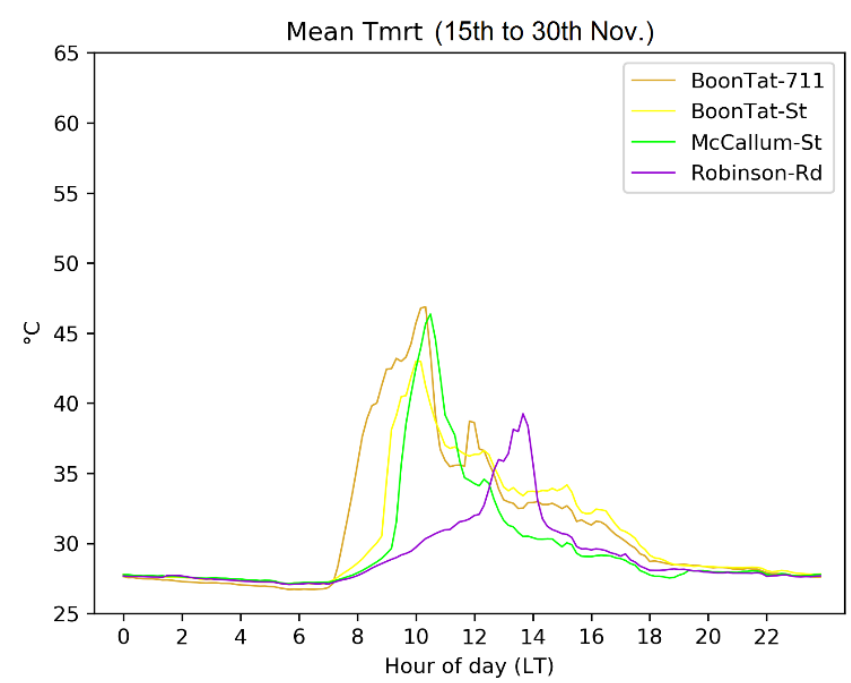

a)

Figure 6. Mean $\mathrm{T}_{\mathrm{mrt}}$ diurnal cycle (using 10-min averaged values) in BoonTat711, BoonTatSt, McCallumSt, and RobinsonRd in the CBD in two different periods: (a) wet Inter-Monsoon (15 to 30 November 2019) and (b) wet NE-Monsoon (30 December 2019 to 13 January 2020).

Peak mean values in these two periods (wet Inter-Monsson and wet NE-Monsoon) are significantly lower than the ones measured in Duxton Park during the SW-Monsoon season, which was mainly due to a lower precipitation (less cloud cover) in the SW-monsoon season and especially in August 2019. In addition, RobinsonRd shows lower mean peak values than the other three sites in the CBD, which can be explained by higher cloud cover and showers during the afternoon that reduce solar incoming radiation at the time when $\mathrm{T}_{\mathrm{mrt}}$ peak occurs. 


\subsection{2. $\mathrm{T}_{\mathrm{mrt}}$ Evaluation on Clear Skies Conditions}

Two specific days were selected to quantify the impact of building shadow on clear skies days: 13 July and 11 October 2019 in the SW-Monsoon and Inter-Monsoon, respectively (Section 3.3). On 13 July, there are some clouds during the morning period, but in the afternoon, clear skies are present (Figure 7). In contrast, 11 October was a clear sky day for Singapore. Both days show similar $\mathrm{T}_{\mathrm{a}}, \mathrm{WS}$, and $e$ mean afternoon values (Table 3 ), but incoming solar radiation differs by $280 \mathrm{Watt} / \mathrm{m}^{2}$ (at the time of the building shadow), which is mostly due to the different time (due to the season) at which the building shadow reaches the sites.
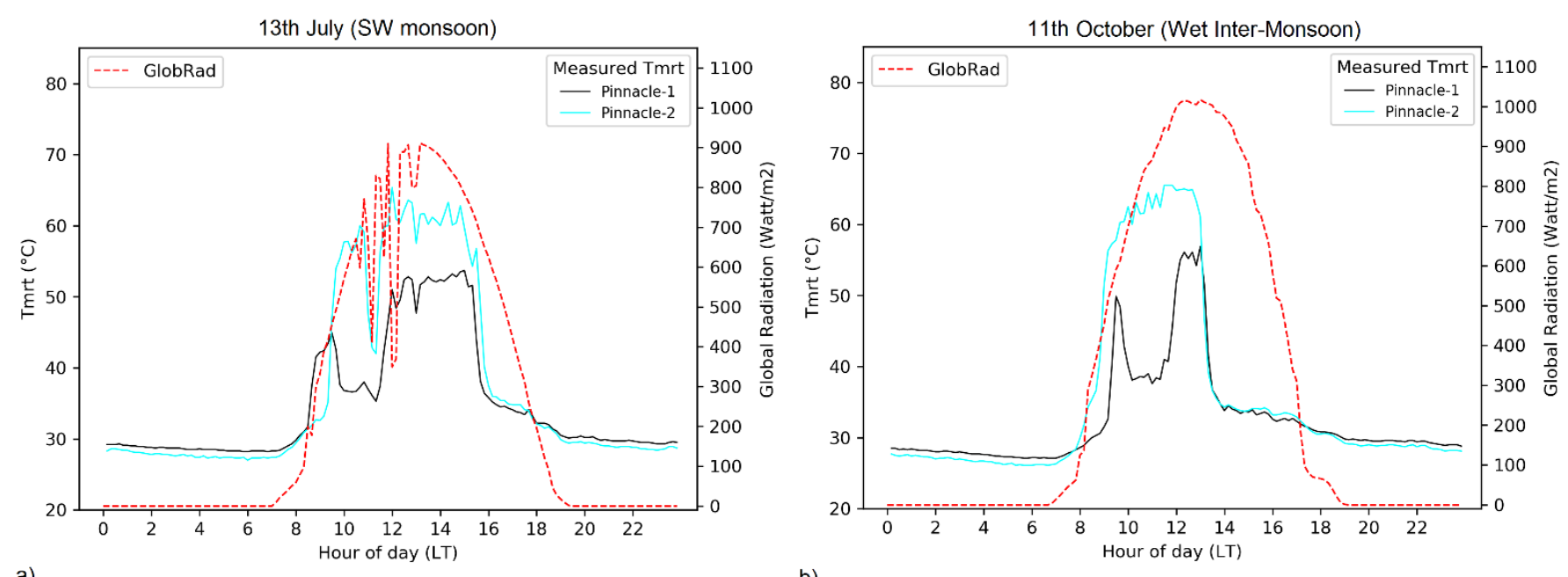

b)

Figure 7. Diurnal cycle of $\mathrm{T}_{\mathrm{mrt}}$ (using 10-min averaged values) and global incoming solar irradiance (using 10-min values) in Pinnacle1 and Pinnacle2 on (a) 13 July and (b) 11 October 2019.

On 11 October, the maximum $\mathrm{T}_{\mathrm{mrt}}$ values reach $65.6^{\circ} \mathrm{C}$ at $12: 40$. Similar values were reported by Tan et al. [28] in Singapore when $\mathrm{T}_{\mathrm{mrt}}$ was estimated on a roof top from six individual measurements/directions of the shortwave radiation and longwave radiation fluxes on a clear sky day. Values were $\approx 69.5^{\circ} \mathrm{C}$ when the shortwave radiation from the sky was $1150 \mathrm{Watt} / \mathrm{m}^{2}$.

Figure 7 shows the $\mathrm{T}_{\mathrm{mrt}}$ diurnal profile for both days. A common result in both days is that the $\mathrm{T}_{\mathrm{mrt}}$ drop due to building shadow is higher in Pinnacle2 since, as commented in Section 4.1.1, Pinnacle 1 is partly affected by tree shadowing before the building effect starts. While in Pinnacle $2 \mathrm{~T}_{\text {mrt }}$ is reduced $\approx 25{ }^{\circ} \mathrm{C}$, Pinnacle $1^{\prime}$ s drop is $\approx 16^{\circ} \mathrm{C}$ (for the case of 13 July). However, higher incoming solar radiation (as on 11 October) causes higher reductions on $\mathrm{T}_{\mathrm{mrt}}$ due to building shadow: $\approx 30^{\circ} \mathrm{C}$ and $\approx 20{ }^{\circ} \mathrm{C}$ for Pinnacle 2 and Pinnacle1, respectively.

The solar trajectory again affects the time when the building shadow reaches each measuring site. A sharp reduction in $\mathrm{T}_{\mathrm{mrt}}$ happens at $\approx 12: 45$ on 11 October (Inter-Monsoon) and at $\approx 15: 15 \mathrm{~h}$ on 13 July (SW-Monsoon). This two-hour difference is $30 \mathrm{~min}$ more than the mean difference between August and October presented in Section 4.1.1.

These results are important to gain an understanding of the benefit of shadowing under clear skies conditions.

\subsection{Effect of Cloudiness}

\subsection{1. $\mathrm{T}_{\mathrm{mrt}}$ Versus the Clearness Index}

$\mathrm{T}_{\mathrm{mrt}}$ values were analyzed based on the levels of cloudiness. Figure 8 shows the relation between the $T_{m r t}$ and the clearness index $\left(K_{t}\right)$ as defined in (2). Two different hours (10:30 and 17:00) are used to represent the morning and late afternoon period in Duxton3 
and Pinnacle2. Duxton3 is non-shaded at both hours, while Pinnacle2 only at 10:30. At 17:00, Pinnacle2 is shaded by the near high-rise building (Figure 3).
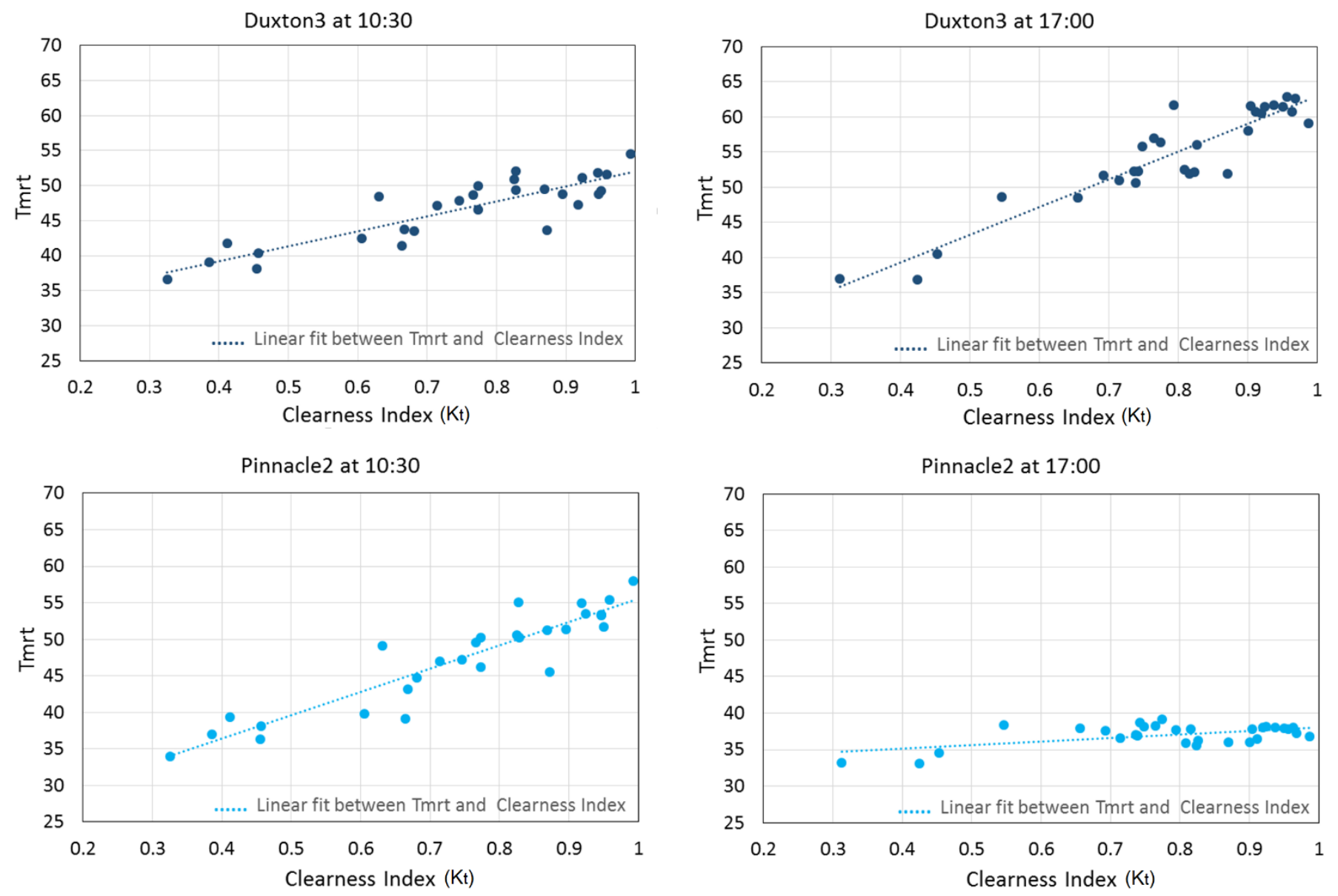

Figure 8. Relation between $\mathrm{T}_{\mathrm{mrt}}$ and the Clearness Index in the shade and non-shaded sites in the morning and afternoon (Duxton3 and Pinnacle2) during August 2019.

Under non-shaded conditions, $\mathrm{T}_{\mathrm{mrt}}$ and $\mathrm{K}_{\mathrm{t}}$ show a good linear relationship (e.g., in Pinnacle2 at 10:30, $\mathrm{r}=0.924(p<0.001))$. The effect of cloudiness on $\mathrm{T}_{\mathrm{mrt}}$ has been presented in other studies (Kántor et al., 2015; Thorsson et al., 2007). However, in the shaded site (17:00 in Pinnacle2), $\mathrm{K}_{\mathrm{t}}$ and $\mathrm{T}_{\mathrm{mrt}}$ have low correlation $(\mathrm{r}=0.558(p<0.001)$ ) (Figure 8), and thus, the level of cloudiness produces low variation in $\mathrm{T}_{\mathrm{mrt}}$ values. In this sense, results highlight the importance of direct solar radiation to govern the variability of $\mathrm{T}_{\mathrm{mrt}}$ levels in Singapore.

Further analysis on the influence of diffuse solar radiation on $\mathrm{T}_{\mathrm{mrt}}$ shows a low relationship between these two variables in shaded sites (Pinnacle2 and Pinnacle1 at 17:00 have $r=0.041(p<0.001)$ and $r=0.297(p<0.001)$ respectively) (Figure 9), suggesting the contribution to $\mathrm{T}_{\mathrm{mrt}}$ of other radiation components (i.e., longwave radiation). The importance of longwave radiation (especially lateral fluxes) to $\mathrm{T}_{\mathrm{mrt}}$ has already been reported in the literature [22,34], which in shaded sites should be higher. On the contrary, in non-shaded sites (Duxton3) at the same hour, diffuse solar radiation and $\mathrm{T}_{\mathrm{mrt}}$ show a negative correlation $(r=-0.520(p<0.001))$. Since higher diffuse radiation is associated with lower direct solar radiation, the results again highlight the role of direct solar radiation in the variability of $\mathrm{T}_{\mathrm{mrt}}$ levels in non-shaded sites. 

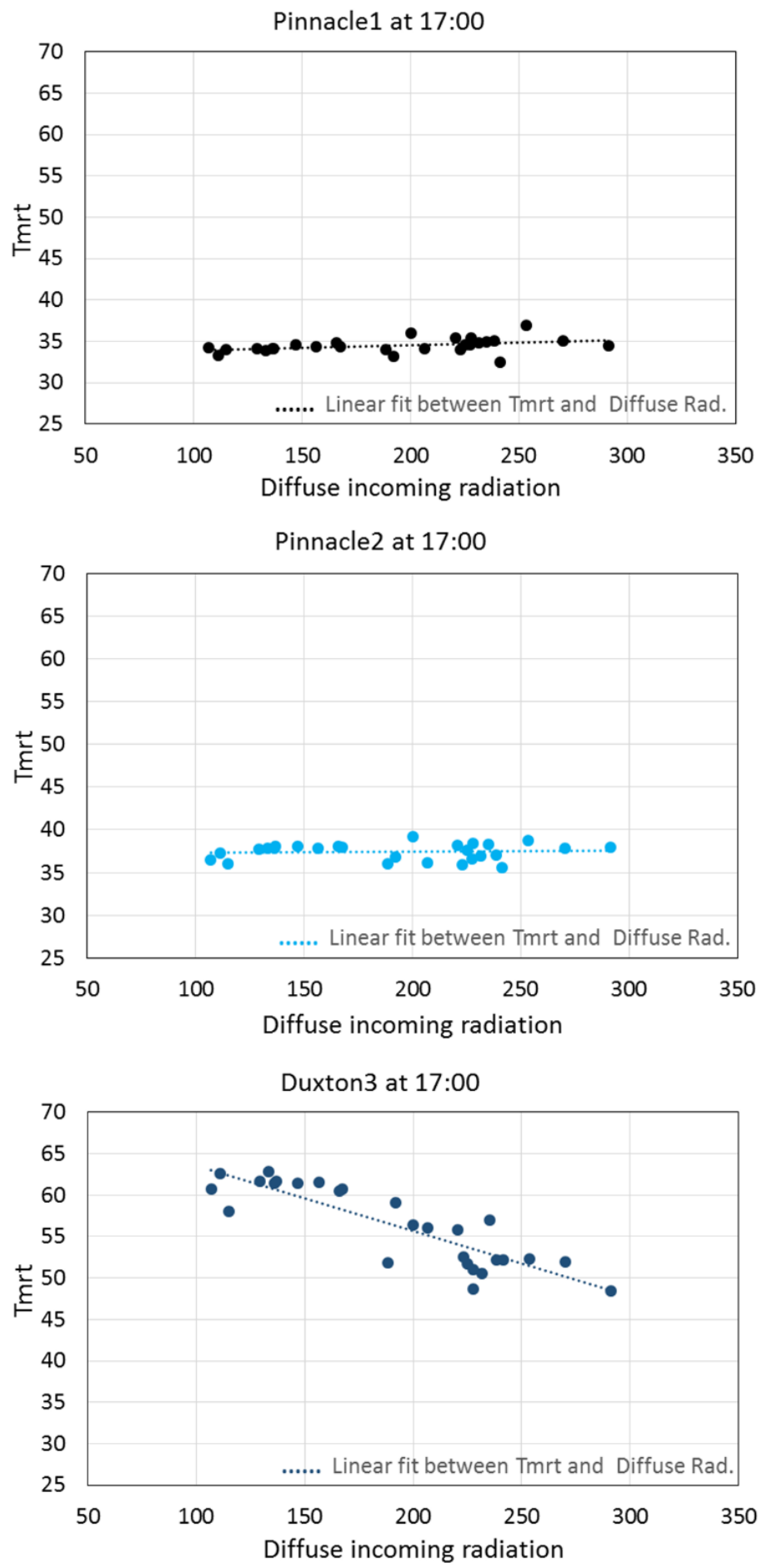

Figure 9. Relation between $\mathrm{T}_{\mathrm{mrt}}\left({ }^{\circ} \mathrm{C}\right)$ and diffuse solar radiation (Watt $\left./ \mathrm{m}^{2}\right)$ in the shaded sites (Pinnacle1 and Pinnacle2) and non-shaded site (Duxton3) in the late afternoon during August 2019 (days with precipitation before 17:00 are not considered).

\subsubsection{Difference between Cloudy and Clear Skies Days}

Analysis of two close non-rainy days in the SW-Monsoon season (25 July and 1 August) has shown the influence of solar radiation levels on $\mathrm{T}_{\mathrm{mrt}}$. On 1 August (clear skies day), $\mathrm{T}_{\mathrm{mrt}}$ values in the three sites (Duxton3, Pinnacle1, and Pinnacle2) show a similar diurnal cycle (Figure 10) to the mean values presented for the SW-Monsoon season (Section 4.1.1), especially in the afternoon (high solar radiation conditions). The effect of building shadowing is clearly noticed in Pinnacle1 and Pinnacle2, starting at 14:50 and 15.20, respectively. 
However, on 25 July (cloudy day), this effect is not as relevant as on a clear skies day (1 August).
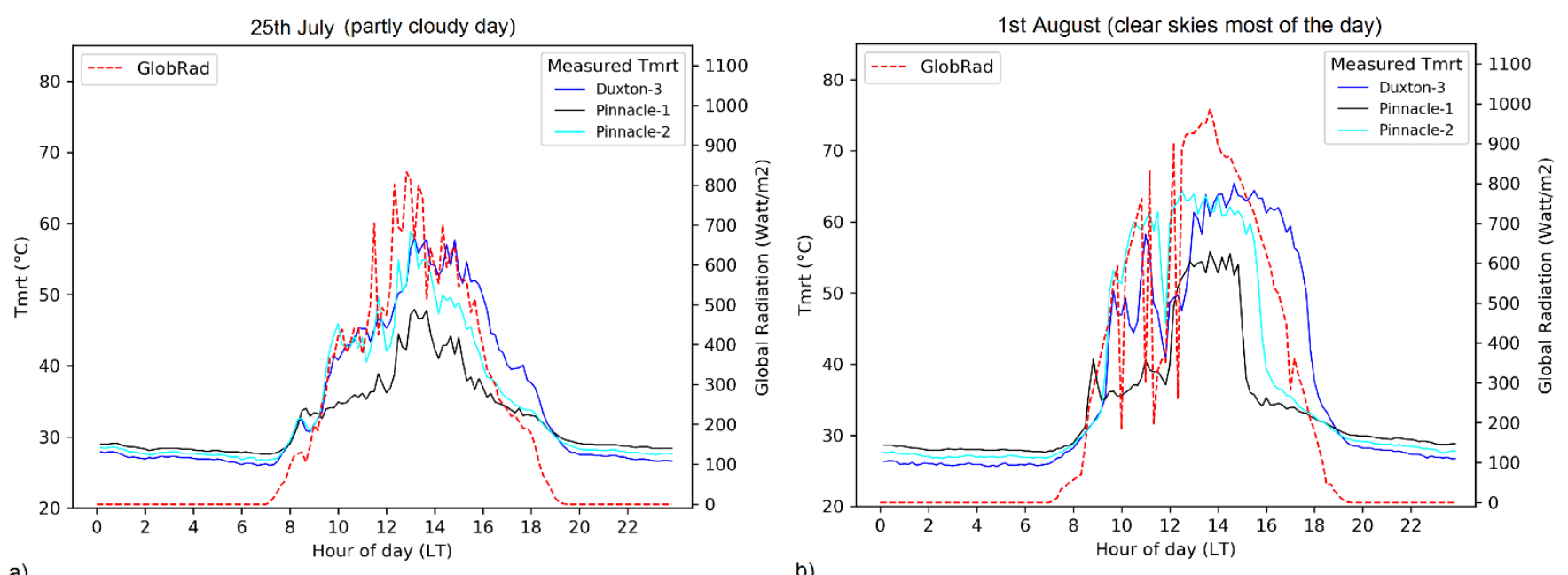

b)

Figure 10. Diurnal cycle of $\mathrm{T}_{\mathrm{mrt}}$ (using 10-min averaged data) and global incoming solar irradiance (using 10-min values) in Duxton3, Pinnacle1, and Pinnacle2 on (a) 1 August 2019 (clear skies during most of the day) and (b) 25 July 2019 (partly cloudy day).

In general, clouds significantly change the $\mathrm{T}_{\mathrm{mrt}}$ diurnal cycle. During the afternoon, cloud cover can reduce $T_{m r t}$ values significantly in sites exposed to direct solar radiation. Between 25 July and 1 August, incoming solar radiation in the $30 \mathrm{~min}$ before the building shadow affected Pinnacle1 differed by $217 \mathrm{Watt} / \mathrm{m}^{2}$ (mean value). During this period (before the building shadow effect), $\mathrm{T}_{\mathrm{mrt}}$ values were lower in the cloudy day (aligned with outcomes in Section 4.1). $\mathrm{T}_{\mathrm{mrt}}$ differences between the two days (cloudy vs. clear day) were $7.8^{\circ} \mathrm{C}, 11.1^{\circ} \mathrm{C}$, and $12.5^{\circ} \mathrm{C}$ in Duxton3, Pinnacle 1, and Pinnacle2 respectively. The lower difference in Duxton3 is associated with a higher sky view factor of the site that allows a higher impact of diffuse radiation under cloudy days.

As expected, a higher decrease in incoming solar radiation causes a higher $\mathrm{T}_{\mathrm{mrt}}$ reduction. In Pinnacle2, before noon (11:00), the $\mathrm{T}_{\mathrm{mrt}}$ difference between the two days (cloudy vs. clear day) reaches $14.2{ }^{\circ} \mathrm{C}$ due to a $400 \mathrm{Watt} / \mathrm{m}^{2}$ difference in the incoming solar radiation.

\subsubsection{Urban Development and Diffuse Radiation}

As commented in the previous section, during cloudy conditions, sites with a higher sky view factor were associated with higher $T_{m r t}$ values due to higher levels of solar diffuse radiation. This was the case in low-rise areas such as Duxton3.

Figure 11 shows the mean $\mathrm{T}_{\mathrm{mrt}}$ values during most of the wet NE-Monsoon season (1 December 2019 to 13 January 2020), when precipitation and cloudiness is highest in Singapore. All sites considered (BoonTatSt, BoonTat711, and McCallumSt) are in NW oriented streets, which causes maximum $\mathrm{T}_{\mathrm{mrt}}$ values to occur at $\approx 10: 00$ am (see Section 4.1.1). During the morning period (until $\approx 9: 30 \mathrm{am}$ ), $\mathrm{T}_{\mathrm{mrt}}$ values are highest in BoonTat711 (partly open urban area and asymmetrical aspect ratio) due to high exposure to solar radiation. At this time of the day, the lowest values are in McCallumSt due to lowest SVF (higher in BoonTat711 and BoonTatSt). After the morning peak $(\approx 10: 00 \mathrm{am}), \mathrm{T}_{\mathrm{mrt}}$ values in all three sites drop $\approx 8^{\circ} \mathrm{C}$. In the midday/afternoon period (11:00 to 16:00), without the direct solar radiation, BoonTatSt and BoonTat711 register similar results. The difference of these two sites with McCallumSt remains quite stable throughout the afternoon. Mean $\mathrm{T}_{\mathrm{mrt}}$ values in McCallumSt are $3.4{ }^{\circ} \mathrm{C}$ and $2.9^{\circ} \mathrm{C}$ lower than BoonTatSt and BoonTat711, respectively. These results are influenced by a lower SVF in McCallum that reduces solar radiation (at this time of the day, only reflected and diffuse radiation) reaching the site in comparison 
to BoonTatSt and BoonTat711 and are in agreement with previous studies that reported higher radiant fluxes inside street canyons with higher SVF. Du et al. [51] showed a positive correlation between SVF and both shortwave and longwave radiation in a severely cold region (Dwa climate type). In a hot and dry region, Middel and Krayenhoff [34] reported that access to solar radiation dominated on $\mathrm{T}_{\mathrm{mrt}}$ together with a positive effect of impervious overheated surfaces on longwave contributions. Although a positive correlation between SVF and $\mathrm{T}_{\mathrm{mrt}}$ during the daytime under direct solar radiation is expected to be found [22,28,52], on shaded sites and with clear skies, SVF can have a weak explanatory power for variations in shortwave fluxes, and $\mathrm{T}_{\mathrm{mrt}}$ can show a negative correlation with SVF; i.e., higher SVF can facilitate a release of longwave radiation and thus decrease $\mathrm{T}_{\mathrm{mrt}}$ in shaded sites [53]. This is not the case in our study area where under building shadow conditions, lower SVF showed lower $\mathrm{T}_{\mathrm{mrt}}$ values. Differences with the study of Lai et al. [53] could be attributed to the frequent cloudy conditions in Singapore that increase the diffuse solar radiation component and thus the solar radiation fluxes in shaded areas. This interpretation is supported by a study from Chatzipoulka et al. [54] analyzing solar radiation in different façade orientations, which found a consistent strong relationship between the SVF and diffuse irradiance and that higher urban openness could increase average diffuse and reflected solar radiation.

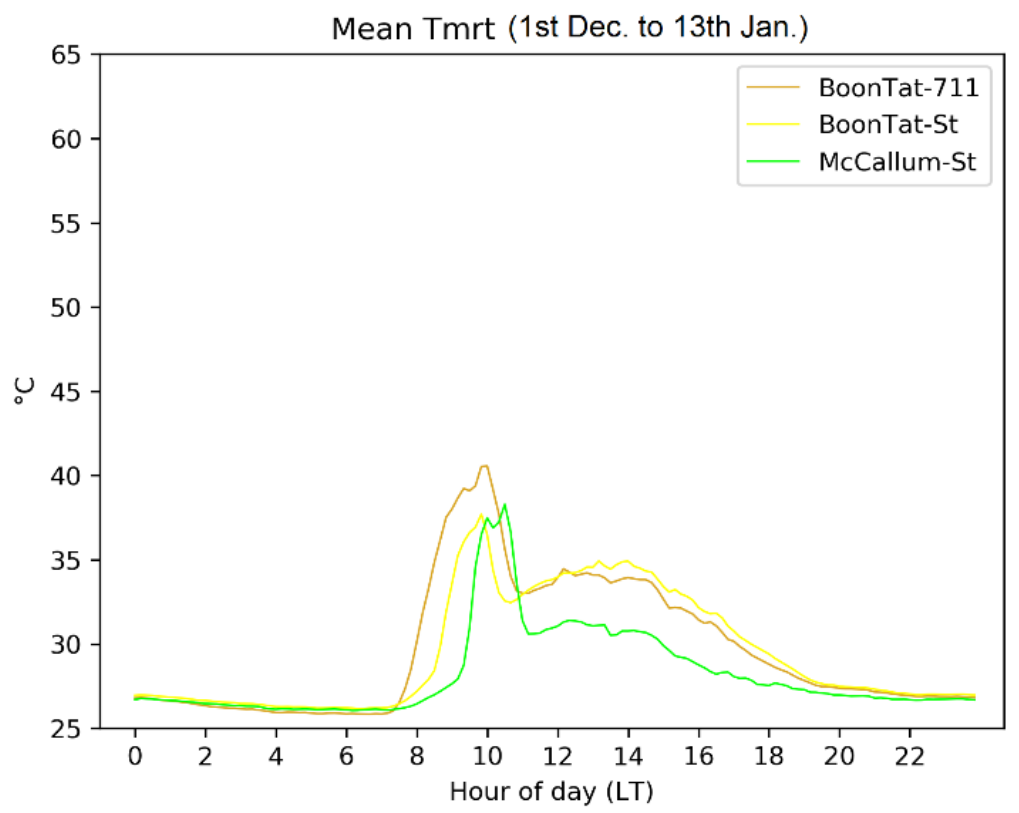

Figure 11. Mean $\mathrm{T}_{\mathrm{mrt}}$ diurnal cycle (from 10-min averaged data) in BoonTat711, BoonTatSt, and McCallumSt in the CBD area during the wet NE-Monsoon season (1 December 2019 to 13 January 2020).

During the evening, $\mathrm{T}_{\mathrm{mrt}}$ difference between BoonTat sites and McCallum slowly reduces. By sunset $(\approx 19: 00)$, when incoming solar radiation is negligible, all three sites register similar $\mathrm{T}_{\mathrm{mrt}}$ values.

Figure 12 represents the effect of increasing the diffuse solar radiation (above the urban canopy) on the $\mathrm{T}_{\mathrm{mrt}}$ difference between a high SVF site (BoonTatSt/BoonTat711) and a low SVF site (McCallumSt) in the absence of direct solar radiation. The diffuse solar radiation is measured at a nearby roof top. Results show that under higher incoming diffuse radiation, the $\mathrm{T}_{\mathrm{mrt}}$ difference between a low SVF and a high SVF site also tends to increase, which is influenced by higher levels of diffuse radiation reaching the pedestrian level in the high SVF site. This outcome is aligned with the result presented in a previous paragraph showing that under shadow conditions, low SVF street canyons reduce radiative fluxes at the pedestrian level and thus show lower $\mathrm{T}_{\mathrm{mrt}}$. 


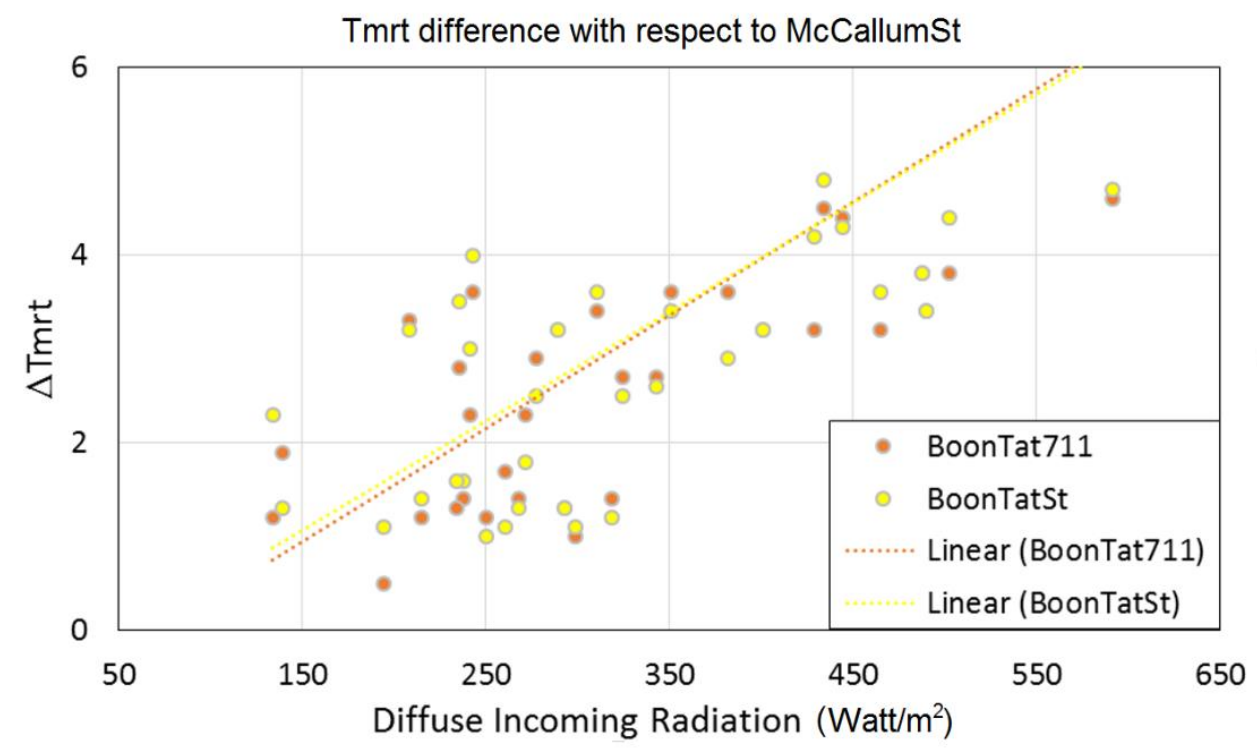

Figure 12. Relation between diffuse solar radiation (above the urban canopy) and the $\mathrm{T}_{\mathrm{mrt}}$ difference $\left(\Delta \mathrm{T}_{\mathrm{mrt}}\right.$ in $\left.{ }^{\circ} \mathrm{C}\right)$ between a low SVF site (BoonTatSt/BoonTat711) and a high SVF site (McCallumSt) in the period 12:00 to 13:00 during the wet NE-Monsoon season (1 December 2019 to 13 January 2020) and under dry conditions.

\section{Conclusions}

In this study, we have analyzed the impact of the shadow of high-rise buildings on $\mathrm{T}_{\mathrm{mrt}}$ as well as the effect of cloudiness and sky view factor in the hot and humid tropical city of Singapore.

Based on measurement campaigns with sensors deployed simultaneously in different sites, the results are presented for different seasons and for specific days (with different level of cloudiness), providing representative $T_{m r t}$ values in the selected sites.

Street orientation and aspect ratio have shown an important impact on $\mathrm{T}_{\mathrm{mrt}}$ due to their influence in solar access at pedestrian level. The street orientation conditions the time when $\mathrm{T}_{\text {mrt }}$ peak values occur (up to $4 \mathrm{~h}$ difference between a NE and a NW-oriented street in the wet NE-Monsoon). The street aspect ratio affects the width of $\mathrm{T}_{\text {mrt }}$ peak (i.e., period of time with highest $\mathrm{T}_{\mathrm{mrt}}$ levels). Compared to high-rise developments, wider (in time) $\mathrm{T}_{\mathrm{mrt}}$ peaks are expected in low-rise and partly open urban areas due to higher exposure to solar radiation. Additionally, $\mathrm{T}_{\mathrm{mrt}}$ diurnal cycles at each site have shown a different pattern throughout the year. Not only can levels of cloudiness vary between seasons but also the change in solar elevation is responsible for $\mathrm{T}_{\mathrm{mrt}}$ peaks occurring at different times and with different intensity throughout the year.

Under clear skies days, the effect of high-rise building shadow produced a $\mathrm{T}_{\mathrm{mrt}}$ reduction of $\approx 25{ }^{\circ} \mathrm{C}$ and $\approx 30{ }^{\circ} \mathrm{C}$ in the SW-Monsoon and wet Inter-Monsoon seasons, respectively. Differences between seasons were conditioned by the solar elevation and thus the time when the building produced shadow on the analyzed site.

On the other hand, cloudiness has a clear effect on $\mathrm{T}_{\mathrm{mrt}}$ in Singapore. On non-shaded sites (after midday), when incoming solar radiation (above the urban canopy) is reduced $\approx 217 \mathrm{Watt} / \mathrm{m}^{2}, \mathrm{~T}_{\mathrm{mrt}}$ levels can be reduced between 7.8 and $12.5^{\circ} \mathrm{C}$ (depending on the sky view factor and surrounding elements).

On shaded sites, the level of diffuse solar radiation (above the urban canopy) does not show a relevant impact on $\mathrm{T}_{\mathrm{mrt}}$, suggesting the influence of longwave radiative fluxes. However, under shaded conditions, the influence of SVF can still be noticed in $\mathrm{T}_{\mathrm{mrt}}$ values at the pedestrian level. In these conditions, a low sky view factor can reduce diffuse the solar radiation reaching the pedestrian level, and thus, $\mathrm{T}_{\mathrm{mrt}}$ is expected to be lower than in sites with higher sky view factors. This effect is emphasized for high levels of diffuse solar radiation (above the urban canopy), which are frequent in Singapore. For the same street 
orientation and during the wet NE-Monsoon, mean afternoon $\mathrm{T}_{\mathrm{mrt}}$ values were $\approx 3.4{ }^{\circ} \mathrm{C}$ higher in low-rise/partly open urban sites than in high-rise development sites.

We consider that these results bring relevant information on $\mathrm{T}_{\mathrm{mrt}}$ values regarding the interaction of incoming radiative fluxes and urban development, and we justify the necessity of a detailed analysis and proper quantification of the effects that govern $\mathrm{T}_{\mathrm{mrt}}$ in different climate contexts as well as the reduction that certain urban features can achieve. This is especially useful for urban planning due to the influence of $\mathrm{T}_{\mathrm{mrt}}$ in outdoor thermal comfort levels.

The measurements presented in this work will serve as a reliable database to evaluate the performance of microscale models to estimate $\mathrm{T}_{\mathrm{mrt}}$. Further work should be focused on the analysis of the contribution of different radiative components (shortwave, longwave) on the $\mathrm{T}_{\mathrm{mrt}}$ levels in different urban developments both on shaded and non-shaded sites. Integral radiation measurements at the pedestrian level would allow improving the radiation schemes of models and thus the estimations and detailed spatial distribution of $\mathrm{T}_{\mathrm{mrt}}$ in the urban area.

Author Contributions: Conceptualization, J.A.A.; Data curation, E.J.Y.K. and Y.S.T.; Formal analysis, J.A.A.; Funding acquisition, L.K.N.; Investigation, J.A.A.; Methodology, J.A.A.; Software, E.J.Y.K. and Y.S.T.; Supervision, L.K.N.; Visualization, E.J.Y.K. and Y.S.T.; Writing-original draft, J.A.A.; Writing - review and editing, J.A.A. All authors have read and agreed to the published version of the manuscript.

Funding: This research was funded by National Research Foundation of Singapore under its Virtual Singapore programme (Grant number: NRF2019VSG-UCD-001).

Institutional Review Board Statement: Not applicable.

Informed Consent Statement: Not applicable.

Data Availability Statement: The data presented in this study are available on request from the corresponding author. The data are not publicly available due to an approval required from the funding organization.

Acknowledgments: The authors would like to thank researchers in CENSAM-SMART, National University of Singapore (NUS), Singapore ETH Center (SEC), and Technical University of Munich (TUM) for the fruitful discussions in the framework of the 'Cooling Singapore' project, and especially to Yuliya Dzyuban, Conrad Philipp Heinz, and Manon Kohler for their help in deploying the sensors. 'Cooling Singapore' is a collaborative project led by the Singapore-ETH Centre (SEC), with SingaporeMIT Alliance for Research and Technology (SMART), TUMCREATE (established by the Technical University of Munich), the National University of Singapore (NUS), the Singapore Management University (SMU), and the Agency for Science, Technology, and Research (A*STAR).

Conflicts of Interest: The authors declare no conflict of interest.

\section{References}

1. United Nations. World Population Prospects: The 2017 Revision, Key Findings and Advanced Tables; Department of Economic and Social Affairs, Population Division: New York, NY, USA, 2017.

2. Aflaki, A.; Mirnezhad, M.; Ghaffarianhoseini, A.; Ghaffarianhoseini, A.; Omrany, H.; Wang, Z.H.; Akbari, H. Urban heat island mitigation strategies: A state-of-the-art review on Kuala Lumpur, Singapore and Hong Kong. Cities 2016, 62, 131-145. [CrossRef]

3. Akbari, H.; Kolokotsa, D. Three decades of urban heat islands and mitigation technologies research. Energy Build. 2016, 133, 834-852. [CrossRef]

4. Rizwan, A.M.; Dennis, L.Y.C.; Liu, C. A review on the generation, determination and mitigation of Urban Heat Island. J. Environ. Sci. 2008, 20, 120-128. [CrossRef]

5. Santamouris, M. Regulating the damaged thermostat of the cities-Status, impacts and mitigation challenges. Energy Build. 2015, 91, 43-56. [CrossRef]

6. Martilli, A.; Krayenhoff, E.S.; Nazarian, N. Is the Urban Heat Island intensity relevant for heat mitigation studies? Urban Clim. 2020, 31, 100541. [CrossRef]

7. Tong, S.; Wong, N.H.; Tan, C.L.; Jusuf, S.K.; Ignatius, M.; Tan, E. Impact of urban morphology on microclimate and thermal comfort in northern China. Sol. Energy 2017, 155, 212-223. [CrossRef] 
8. Yang, J.; Bou-Zeid, E. Should cities embrace their heat islands as shields from extreme cold? J. Appl. Meteorol. Climatol. 2018, 57, 1309-1320. [CrossRef]

9. Ali-Toudert, F.; Mayer, H. Numerical study on the effects of aspect ratio and orientation of an urban street canyon on outdoor thermal comfort in hot and dry climate. Build. Environ. 2006, 41, 94-108. [CrossRef]

10. Herrmann, J.; Matzarakis, A. Mean radiant temperature in idealised urban canyons-examples from Freiburg, Germany. Int. J. Biometeorol. 2012, 56, 199-203. [CrossRef] [PubMed]

11. Yang, W.; Wong, N.H.; Li, C.-Q. Effect of Street Design on Outdoor Thermal Comfort in an Urban Street in Singapore. J. Urban Plan. Dev. 2016, 142, 05015003. [CrossRef]

12. Urban Climate Challenges in the Tropics. In Rethinking Planning and Design Opportunities; Emmanuel, R. (Ed.) Imperial College Press: London, UK, 2016; ISBN 9781783268405.

13. Bourbia, F.; Boucheriba, F. Impact of street design on urban microclimate for semi arid climate (Constantine). Renew. Energy 2010, 35, 343-347. [CrossRef]

14. Chatzidimitriou, A.; Yannas, S. Street canyon design and improvement potential for urban open spaces; the influence of canyon aspect ratio and orientation on microclimate and outdoor comfort. Sustain. Cities Soc. 2017, 33, 85-101. [CrossRef]

15. Djekic, J.; Djukic, A.; Vukmirovic, M.; Djekic, P.; Brankovic, M.D. Thermal comfort of pedestrian spaces and the influence of pavement materials on warming up during summer. Energy Build. 2018, 159, 474-485. [CrossRef]

16. Doulos, L.; Santamouris, M.; Livada, I. Passive cooling of outdoor urban spaces. The role of materials. Sol. Energy 2004, 77, 231-249. [CrossRef]

17. Alexandri, E.; Jones, P. Temperature decreases in an urban canyon due to green walls and green roofs in diverse climates. Build. Environ. 2008, 43, 480-493. [CrossRef]

18. Ali-Toudert, F.; Mayer, H. Effects of asymmetry, galleries, overhanging façades and vegetation on thermal comfort in urban street canyons. Sol. Energy 2007, 81, 742-754. [CrossRef]

19. Kong, L.; Lau, K.K.-L.; Yuan, C.; Chen, Y.; Xu, Y.; Ren, C.; Ng, E. Regulation of Outdoor Thermal Comfort by Trees in Hong Kong. Sustain. Cities Soc. 2017, 31, 12-25. [CrossRef]

20. de Munck, C.; Pigeon, G.; Masson, V.; Meunier, F.; Bousquet, P.; Tréméac, B.; Merchat, M.; Poeuf, P.; Marchadier, C. How much can air conditioning increase air temperatures for a city like Paris, France? Int. J. Climatol. 2013, 33, 210-227. [CrossRef]

21. Ohashi, Y.; Genchi, Y.; Kondo, H.; Kikegawa, Y.; Yoshikado, H.; Hirano, Y. Influence of Air-Conditioning Waste Heat on Air Temperature in Tokyo during Summer: Numerical Experiments Using an Urban Canopy Model Coupled with a Building Energy Model. J. Appl. Meteorol. Climatol. 2007, 46, 66-81. [CrossRef]

22. Lee, H.; Mayer, H.; Schindler, D. Importance of 3-D radiant flux densities for outdoor human thermal comfort on clear-sky summer days in Freiburg, Southwest Germany. Meteorol. Z. 2014, 23, 315-330. [CrossRef]

23. Manavvi, S.; Rajasekar, E. Estimating outdoor mean radiant temperature in a humid subtropical climate. Build. Environ. 2020, 171, 106658. [CrossRef]

24. ISO7726. Ergonomics of the Thermal Environment-Instruments for Measuring Physical Quantities; International Standarization Organization: Geneva, Switzerland, 1998; ISBN 0-580-38651-1.

25. Acero, J.A.; Herranz-Pascual, K. A comparison of thermal comfort conditions in four urban spaces by means of measurements and modelling techniques. Build. Environ. 2015, 93, 245-257. [CrossRef]

26. Mayer, H.; Holst, J.; Dostal, P.; Imbery, F.; Schindler, D. Human thermal comfort in summer within an urban street canyon in Central Europe. Meteorol. Z. 2008, 17, 241-250. [CrossRef]

27. Kántor, N.; Unger, J. The most problematic variable in the course of human-biometeorological comfort assessment-The mean radiant temperature. Cent. Eur. J. Geosci. 2011, 3, 90-100. [CrossRef]

28. Tan, C.L.; Wong, N.H.; Jusuf, S.K. Outdoor mean radiant temperature estimation in the tropical urban environment. Build. Environ. 2013, 64, 118-129. [CrossRef]

29. Kuehn, L.A.; Stubbs, R.A.; Weaver, R.S. Theory of the globe thermometer. J. Appl. Physiol. 1970, 29, 750-757. [CrossRef]

30. De Dear, R. Ping-pong globe thermometers for mean radiant temperatures. $H V$ Eng. 1987, 60, $10-11$.

31. Herrmann, J.; Matzarakis, A. Influence of mean radiant temperature on thermal comfort of humans in idealized urban environments. In Proceedings of the 7th Conference on Biometeorology, Freiburg, Germany, 12-14 April 2010; pp. $522-527$.

32. Lin, T.P.; Matzarakis, A.; Hwang, R.L. Shading effect on long-term outdoor thermal comfort. Build. Environ. 2010, 45, $213-221$. [CrossRef]

33. Chen, L.; Yu, B.; Yang, F.; Mayer, H. Intra-urban differences of mean radiant temperature in different urban settings in Shanghai and implications for heat stress under heat waves: A GIS-based approach. Energy Build. 2016, 130, 829-842. [CrossRef]

34. Middel, A.; Krayenhoff, E.S. Micrometeorological determinants of pedestrian thermal exposure during record-breaking heat in Tempe, Arizona: Introducing the MaRTy observational platform. Sci. Total Environ. 2019, 687, 137-151. [CrossRef] [PubMed]

35. Kántor, N.; Kovács, A.; Lin, T.-P. Looking for simple correction functions between the mean radiant temperature from the "standard black globe" and the "six-directional" techniques in Taiwan. Theor. Appl. Climatol. 2015, 121, 99-111. [CrossRef]

36. Crank, P.J.; Middel, A.; Wagner, M.; Hoots, D.; Smith, M.; Brazel, A. Validation of seasonal mean radiant temperature simulations in hot arid urban climates. Sci. Total Environ. 2020, 749, 141392. [CrossRef]

37. Monteith, J.L.; Unsworth, M.H. Principles of Environmental Physics, 2nd ed.; Edward Arnold: London, UK, $1990 ;$ p. 197.

38. Oke, T.R. Boundary Layer Climates; Routledge: New York, NY, USA, 1987. 
39. McArthur, L.J.B.; Hay, J.E. A technique for mapping the distribution of diffuse solar radiation over the sky hemisphere. J. Appl. Meteorol. 1981, 20, 421-429. [CrossRef]

40. Reindl, D.T.; Beckman, W.A.; Duffie, J.A. Diffuse fraction correlations. Sol. Energy 1990, 45, 1-7. [CrossRef]

41. Singapore Department of Statistics. Population Trends 2016; Singapore Department of Statistics: Singapore, 2017; ISBN 1793-2424.

42. Roth, M.; Chow, W.T.L. A historical review and assessment of urban heat island research in Singapore. Singap. J. Trop. Geogr. 2012, 33, 381-397. [CrossRef]

43. Chow, W.T.L.; Roth, M. Temporal dynamics of the urban heat island o Singapore. Int. J. Climatol. 2006, 26, 2243-2260. [CrossRef]

44. Acero, J.A.; Koh, E.J.Y.; Tan, Y.S. Analysis of Climatic Variables in Different Urban Sites of Singapore and Evaluation of Strategies to Improve the Outdoor Thermal Environment; Technical Report. ETH Collection 2020. [CrossRef]

45. Tetens, O. Uber einige meteorologische Begriffe. Z. Geophys 1930, 6, 297-309.

46. Acero, J.A.; Dissegna, M.A.; Tan, Y.S.; Tan, A.; Norford, L.K. Outdoor performance of the black globe temperature sensor on a hot and humid tropical region. Environ. Technol. 2021. Manuscript Submitted for Publication.

47. Nobre, A.M.; Dazhi, Y.; Tan, A.L.; Thome, E.R.; Tan, J.; Tan, A.D. Large-area 2D mapping of PV system performace. In Proceedings of the 29th European Photovoltaic Solar Energy Conference, Amsterdam, The Netherlands, 22-26 September 2014.

48. Matzarakis, A.; Rutz, F.; Mayer, H. Modelling radiation fluxes in simple and complex environments-Application of the RayMan model. Int. J. Biometeorol. 2007, 51, 323-334. [CrossRef]

49. Matzarakis, A.; Rutz, F.; Mayer, H. Modelling radiation fluxes in simple and complex environments: Basics of the RayMan model. Int. J. Biometeorol. 2010, 54, 131-139. [CrossRef]

50. Dazhi, Y.; Jirutitijaroen, P.; Walsh, W.M. The Estimation of Clear Sky Global Horizontal Irradiance at the Equator. Energy Procedia 2012, 25, 141-148. [CrossRef]

51. Du, J.; Sun, C.; Xiao, Q.; Chen, X.; Liu, J. Field assessment of winter outdoor 3-D radiant environment and its impact on thermal comfort in a severely cold region. Sci. Total Environ. 2020, 709, 136175. [CrossRef]

52. Krüger, E.L.; Minella, F.O.; Rasia, F. Impact of urban geometry on outdoor thermal comfort and air quality from field measurements in Curitiba, Brazil. Build. Environ. 2011, 46, 621-634. [CrossRef]

53. Lai, A.; Maing, M.; Ng, E. Observational studies of mean radiant temperature across different outdoor spaces under shaded conditions in densely built environment. Build. Environ. 2017, 114, 397-409. [CrossRef]

54. Chatzipoulka, C.; Compagnon, R.; Kaempf, J.; Nikolopoulou, M. Sky view factor as predictor of solar availability on building façades. Sol. Energy 2018, 170, 1026-1038. [CrossRef] 